\title{
Oxygen-minimum zone sediments in the northeastern Arabian Sea off Pakistan: a habitat for the bacterium Thioploca
}

\author{
Rolf Schmaljohann ${ }^{1, *}$, Manuela Drews ${ }^{1}$, Sylvia Walter ${ }^{1}$, Peter Linke $^{2}$, \\ Ulrich von $\operatorname{Rad}^{3}$, Johannes F. Imhoff ${ }^{1}$ \\ ${ }^{1}$ Institut für Meereskunde an der Universität Kiel, Marine Mikrobiologie, Düsternbrooker Weg 20, 24105 Kiel, Germany \\ ${ }^{2}$ GEOMAR Forschungszentrum für Marine Geowissenschaften, Wischhofstr. 1-3, 24148 Kiel, Germany \\ ${ }^{3}$ Bundesanstalt für Geowissenschaften und Rohstoff, Postfach 510153, 30631 Hannover, Germany
}

\begin{abstract}
Filamentous sulfur-oxidizing bacteria and geochemical parameters of sediments at the Makran accretionary wedge in the northeastern Arabian Sea off Pakistan were studied. The upper continental slope between 350 and $850 \mathrm{~m}$ water depth, which is in the center of the oxygen-minimum zone, is characterized by numerous sites of small-scale seeps of methane- and sulfide-charged porewater. White bacterial mats with diameters $<1 \mathrm{~m}$ were discovered at the surface of these sites using a photo-TV sled. Seep sediments, as well as non-seep sediments, in the vicinity were characterized by the occurrence of the bacterium Thioploca in near-surface layers between 0 and $13 \mathrm{~cm}$ depth. Thioploca bundles were up to $20 \mathrm{~mm}$ in length and contained up to 20 filaments of varying diameters, between 3 and $75 \mu \mathrm{m}$. Up to 169 ind. $\mathrm{cm}^{-2}$ were counted. Maximum numbers occurred in the top $9 \mathrm{~cm}$ of sediment, which contained very low concentrations of soluble sulfide $(<0.2 \mu \mathrm{M})$ and high amounts

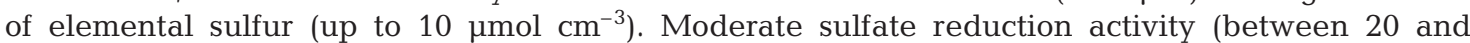
$190 \mathrm{nmol} \mathrm{cm}^{-3} \mathrm{~d}^{-1}$ ) was detected in the top $10 \mathrm{~cm}$ of these sediments, resulting in a gradual downcore decrease of sulfate concentrations. $\mathrm{CO}_{2}$ fixation rates had distinct maxima at the sediment surface and declined to background values below $5 \mathrm{~cm}$ depth. The nutritional implications of the distinct morphology of Thioploca and of the geochemical setting are discussed and compared to other sites containing Thioploca communities.
\end{abstract}

KEY WORDS: Thioploca · Beggiatoa · Arabian Sea · Cold seeps · Oxygen-minimum zone sediments · Filamentous sulfur-oxidizing bacteria $\cdot$ Sulfate reduction rates $\cdot \mathrm{CO}_{2}$ fixation rates

\section{INTRODUCTION}

The northeastern Arabian Sea is characterized by its high biological productivity, especially during the summer monsoon, and an exceptionally stable and broad mid-water oxygen-minimum zone (OMZ) between 150 and $1100 \mathrm{~m}$ water depth (Wyrtki 1973). In the area, where the OMZ impinges on the continental slope, sediments consisting of laminated muds rich in organic matter and with sedimentation rates up to $1 \mathrm{~mm} \mathrm{yr}^{-1}$ were discovered (Von Stackelberg 1972, Von Rad et al. 2000). The southern part of Pakistan (Makran), including the adjoining shelf region, is an active subduction zone,

*E-mail: rschmaljohann@ifm.uni-kiel.de which is expressed by the formation of a number of accretionary ridges in water depths between 1500 and $2800 \mathrm{~m}$ and by gas seepage at the upper continental slope between 350 and 850 m (Von Rad et al. 1996). Seep structures observed in this area by photo-TV sled include small-scale gas expulsion structures of a few centimeters diameter and small pockmarks ( $<1 \mathrm{~m}$ diameter), frequently accompanied by authigenic carbonates and bacterial mats (Von Rad et al. 1996). During a previous cruise ('Sonne-90', September 1993) benthic life at the sediment surface of the investigation area was monitored by a photo-TV sled along profiles from shallow to deep water. In dependency on the oxygen concentration of the overlying water, 5 facies zones could be differentiated (Von Rad et al. 1996): 
1. Upper oxic zone (above $270 \mathrm{~m}$ water depth), defined by very strong bioturbation (burrows a few centimeters apart) and abundant benthic life (mollusks, bryozoans, pennatulids, etc.);

2. Upper suboxic zone (270 to $430 \mathrm{~m}$ water depth), defined by considerably less bioturbation, abundant sessile tube worms, and a few fish;

3. Central suboxic zone (430 to $940 \mathrm{~m}$ water depth), defined by an almost complete lack of bioturbation and benthic life, and the presence of dead fish. A surface layer of olive-green, fluffy material was observed during the late summer monsoon;

4. Lower suboxic zone (940 to $1100 \mathrm{~m}$ water depth), defined by the appearance of some bioturbation, abundant tube worms (as in Zone 2), crabs, and a few fish;

5. Lower oxic zone (below $1100 \mathrm{~m}$ water depth), defined by abundant bioturbation and benthic life (sponges, gorgonians, crabs, sea urchins, pennatulids, worms, serpulid worms) and abundant fish.

Bacterial mats, observed in the central suboxic zone, were not examined by microbiological methods during that cruise. Generally, bacterial mats like those found in sediments of a comparable OMZ off the Chilean coast are composed of filamentous sulfur bacteria of the genera Beggiatoa and/or Thioploca (Schulz et al. 1996). Both types of filaments consist of large-diameter, colorless sulfur bacteria containing elemental sulfur inclusions and large vacuoles within their cells. Both genera are phylogenetically closely related and can be separated morphologically only by the existence of a sheath surrounding a bundle of filaments in Thioploca (Teske et al. 1995). These bacteria are facultative chemolithoautotrophs, capable of gaining energy by the oxidation of sulfide with oxygen or nitrate, and of mixotrophic growth using organic compounds like acetate (Hagen \& Nelson 1996, Otte et al. 1999). High concentrations of nitrate in the vacuoles, which can be used by the gliding filaments as their electron acceptor in deeper sediment layers with available sulfide, have been found in representatives of both genera (Fossing et al. 1995, McHatton et al. 1996). Physiological differences between both genera seem to be indicated by the preference of very low sulfide and oxygen concentrations by Thioploca, while Beggiatoa mats are generally found at sharp gradients between high sulfide concentrations in the sediment and sufficient oxygen contents in the overlying water (Jørgensen \& Gallardo 1999). As a consequence Thioploca communities have been found mainly in low-sulfide environments overlain by constant low-oxygen water columns, for example, off the Chilean coast (Gallardo 1977), off Namibia (Gallardo et al. 1998) and off Oman (Levin et al. 1997), whereas Beggiatoa mats are more wide-spread on numerous high-sulfide sediments, including vent sites (Jannasch et al. 1989).

It was the objective of the 'SO-130' cruise in April 1998 to sample the sediments located in the OMZ of the northeastern Arabian Sea and to investigate the bacterial mats along with bacterial activities and geochemical parameters in the sediments. In the present study the morphology and the distribution of the observed Thioploca/Beggiatoa community, as well as the environmental conditions, will be compared to other known Thioploca sites.

\section{MATERIAL AND METHODS}

Sampling. During cruise 'SO-130' with RV 'Sonne' from 3 April to 2 May 1998, 25 box corer and multicorer sediment samples from different water depths in the investigated area (Fig. 1) were examined for bacterial mats. One station in the western part of this area (Stn 223) and another station in the eastern part (Stn 309) were selected for a detailed investigation of sediment parameters and bacterial activities. These stations, together with an additional site (Stn 257; $24^{\circ} 55.71^{\prime} \mathrm{N}, 65^{\circ} 50.15^{\prime} \mathrm{E} ; 417 \mathrm{~m}$ water depth) were situated within a seep field. It was not possible to lower the multicorer, without TV control, directly onto 1 of the small-scale bacterial mats $(<1 \mathrm{~m}$ diameter $)$. Small sediment cores that were attached to a benthic chamber (VESP 1, Geomar Kiel, Germany), which was lowered directly on a seep structure, provided additional information on sediment from the margin of a seep site (Stns 232 and 304). Another seep site was sampled by a TV-controlled large grab (Stn 302; $24^{\circ} 49.88^{\prime} \mathrm{N}, 65^{\circ} 54.25^{\prime} \mathrm{E}$; $850 \mathrm{~m}$ deep). An overview of the stations, their locations, the sampling methods and the key characteristics of sediment cores is given in Table 1. We obtained additional information on the distribution of bacterial mats in the area by the use of a photo-TV sled (OFOS), which was towed along profiles through the OMZ.

Microscopy. Fresh material for light microscopy of bacterial mats was picked from the surface of sediment cores within a few hours after sampling and investigated with a Zeiss III photomicroscope. The number and length of Thioploca sheaths in a sediment sample was determined by suspending $1 \mathrm{~cm}^{3}$ of sediment in a petri dish with seawater and by sorting out and measuring the sheaths with the aid of a stereomicroscope.

Samples for scanning electron microscopy (SEM) were fixed on board with $2 \%$ formaldehyde and later dehydrated with an ethanol series, critical point dried and sputter coated. Photomicrographs were taken with a Zeiss DSM 940 digital scanning microscope. 


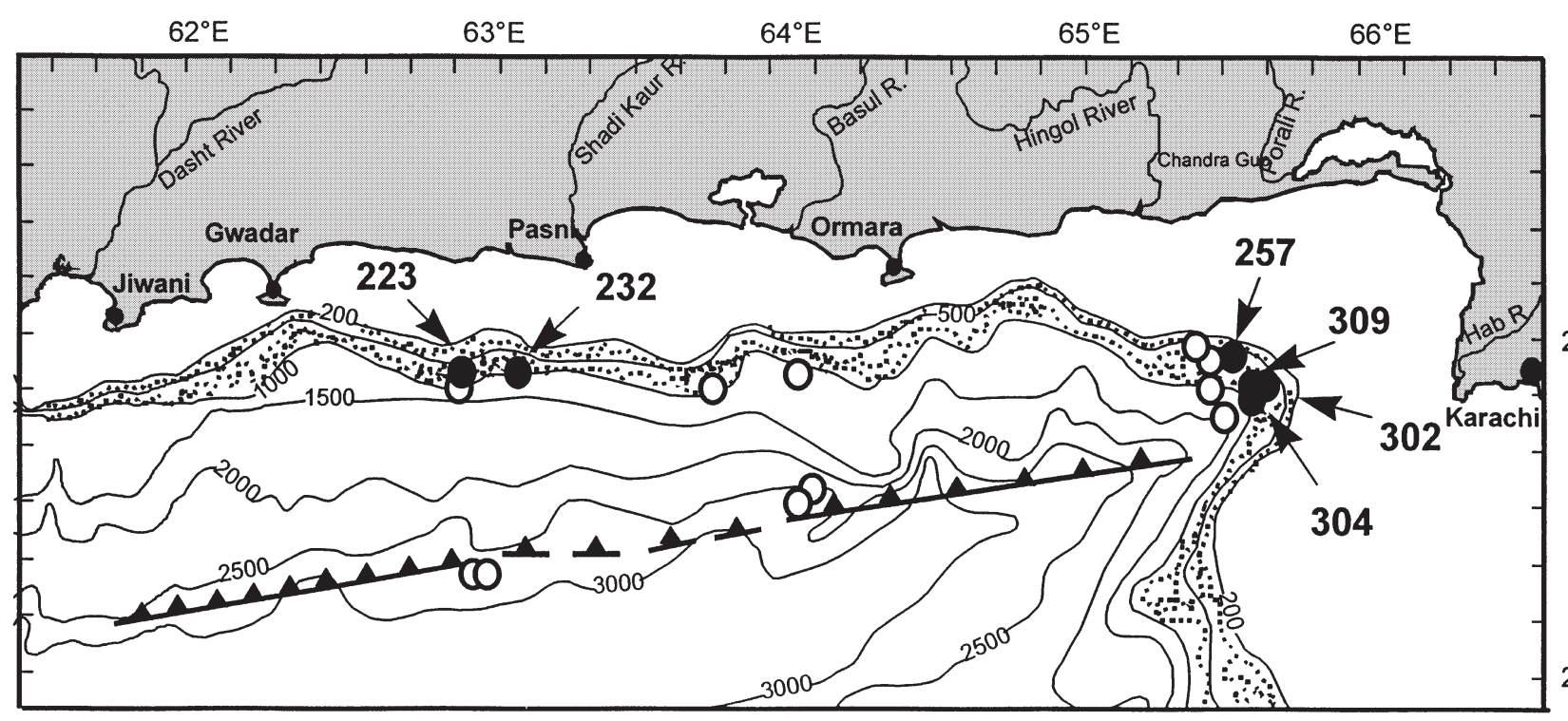

Fig. 1. Map of the investigation area showing the stations with $(\bullet)$ and without (0) Thioploca communities in the sediment. The area where the oxygen-minimum zone impinges on the sediment is dotted; the deformation front of the subduction zone is also marked

Further material from the bacterial mats was fixed for transmission electron microscopy (TEM). Samples were pre-fixed for $6 \mathrm{~h}$ with $3 \%$ glutaraldehyde in sucrose-cacodylate buffer, rinsed, post-fixed for $3 \mathrm{~h}$ with $1 \%$ osmium tetroxide in cacodylate buffer, dehydrated with an ethanol series and embedded via propylene oxide in ERL epoxy resin. Ultrathin sections were made with a Reichert OMU 3 ultramicrotome. After staining with uranyl acetate and lead citrate, sections were analyzed with a Philips EM 300 transmission electron microscope.

Geochemical sediment parameters. For direct measurements of the redox potential within sediment cores up to $20 \mathrm{~cm}$ depth, a very thin (400 $\mu \mathrm{m}$ tip diameter) and $22 \mathrm{~cm}$ long Pt-redox electrode (made by Stefan
Zimmermann, Institut für Meereskunde, Kiel, Germany) was used. A Mettler Toledo InLab 301 was used as a reference electrode. The electrodes were inserted into the fresh sediment in steps of $1 \mathrm{~cm}$. The measured redox potential was transformed to the reference potential of a normal $\mathrm{H}_{2}$-electrode and documented as 'Eh'.

Porewater of sediment slices from different sediment depths was obtained by centrifugation for $10 \mathrm{~min}$ at $4000 \mathrm{rpm}$ (approx. $1700 \times g$ ) and $4^{\circ} \mathrm{C}$ in a Sigma $302 \mathrm{~K}$ centrifuge in completely filled and gas-tight tubes. For determination of hydrogen sulfide, an aliquot of the supernatant porewater was fixed immediately after centrifugation in $2 \%$ zinc acetate (w/v) with the addition of $0.1 \% 2 \mathrm{M}$ acetic acid. The precipitated sulfide was measured photometrically as methylene blue (ab-

Table 1. Location of sites, sampling methods and key characteristics of Thioploca-containing sediment cores from the Arabian Sea

\begin{tabular}{|c|c|c|c|c|}
\hline & Stn 223 & Stn 309 & Stn 232 & Stn 304 \\
\hline Water depth $(\mathrm{m})$ & 580 & 608 & 613 & 849 \\
\hline Location & $\begin{array}{l}24^{\circ} 54.65^{\prime} \mathrm{N} \\
63^{\circ} 02.34^{\prime} \mathrm{E}\end{array}$ & $\begin{array}{l}24^{\circ} 51.52^{\prime} \mathrm{N} \\
65^{\circ} 57.78^{\prime} \mathrm{E}\end{array}$ & $\begin{array}{l}24^{\circ} 53.98^{\prime} \mathrm{N} \\
63^{\circ} 12.18^{\prime} \mathrm{E}\end{array}$ & $\begin{array}{l}24^{\circ} 49.87^{\prime} \mathrm{N} \\
65^{\circ} 54.22^{\prime} \mathrm{E}\end{array}$ \\
\hline Sampling gear & \multicolumn{2}{|c|}{ Multiple corer, not TV-controlled } & \multicolumn{2}{|c|}{ Corer attached to benthic chamber, TV-controlled } \\
\hline Position to seeps & \multicolumn{2}{|c|}{ Not known, within seep field } & \multicolumn{2}{|c|}{ Marginal area of a bacterial mat-covered seep } \\
\hline Sulfide concentrations & \multicolumn{2}{|c|}{$\begin{array}{l}\text { Very low }(<0.2-18 \mu \mathrm{M}) \text { throughout } \\
\text { the top } 20 \mathrm{~cm}\end{array}$} & \multicolumn{2}{|c|}{ Increasing to $0.25-1.2 \mathrm{mM}$ below $10 \mathrm{~cm}$ depth } \\
\hline Redox potential & \multicolumn{2}{|c|}{$\begin{array}{l}\text { No steep gradients in the top } 15 \mathrm{~cm} \text {; staying } \\
\text { in the positive range within the top } 20 \mathrm{~cm}\end{array}$} & \multicolumn{2}{|c|}{$\begin{array}{l}\text { Steep gradients between } 7 \text { and } 14 \mathrm{~cm} \text { depth; partly } \\
\text { decreasing to negative values below that }\end{array}$} \\
\hline Thioploca distribution & \multicolumn{2}{|c|}{$\begin{array}{l}\text { High numbers between } 0 \text { and } 9 \mathrm{~cm} \text { depth, } \\
\text { single sheaths down to } 15 \mathrm{~cm} \text { depth }\end{array}$} & \multicolumn{2}{|c|}{$\begin{array}{l}\text { High numbers between } 0 \text { and } 5 \mathrm{~cm} \text {, no sheaths } \\
\text { below } 8 \mathrm{~cm} \text { depth }\end{array}$} \\
\hline
\end{tabular}


sorbance $668 \mathrm{~nm}$ ) according to Cline (1969). The detection limit was at $0.2 \mu \mathrm{M}$.

The porewater was filtered through a $0.2 \mu \mathrm{m}$ pore size cellulose acetate filter (Sartorius, Göttingen, Germany) and frozen at $-20^{\circ} \mathrm{C}$ until measurements by ion chromatography (Dionex System 300, AS3500 autosampler with sample preparation and cooling system, Idstein, Germany). Separation of sulfate and nitrate was performed on an anion exchange column (Ionpack-AS4A SC, Dionex, Idstein, Germany) and anions were eluted with $1.7 \mathrm{mM} \mathrm{NaHCO}_{3}+1.8 \mathrm{mM} \mathrm{Na}_{2} \mathrm{CO}_{3}$ (flow rate $2 \mathrm{ml} \mathrm{min}{ }^{-1}$ ). The samples were cooled in the autosampler at $4^{\circ} \mathrm{C}$. Quantitative analyses were made using suppressed conductivity and UV-absorbance at $215 \mathrm{~nm}$ for detection. Integration of the chromatograms was performed by PC-integration software (Dionex Peak Net 5.01).

For determination of elemental sulfur, fresh sediment samples were fixed in a $20 \%$ zinc acetate solution (w/v) in closed glass tubes and stored for several weeks. Two extractions were done with petrol ether shaking for $18 \mathrm{~h}$ at $60 \mathrm{rpm}$. An aliquot of the petrol ether phase was transferred to a sample vial and evaporated completely to dryness. The dry deposit was redissolved in methanol/chloroform (5:1) for ion chromatography. The determination of elemental sulfur was performed by using the Dionex system with a 100 RP18 125/4.5 $\mu \mathrm{m}$ column (Merck) and UV-detection $(263 \mathrm{~nm})$. The elution was done with $95 \%$ methanol + $5 \%$ Milli-Q pure water at a flow rate of $1 \mathrm{ml} \mathrm{min}^{-1}$. For calibration, finely powdered flowers of sulfur (Merck) were used.

Dry weight and water content were measured by weighing sediment samples before and after heating for $24 \mathrm{~h}$ at $80^{\circ} \mathrm{C}$. The amount of organic matter was determined as loss on ignition of dried samples by heating at $550^{\circ} \mathrm{C}$ for $6 \mathrm{~h}$.

For determination of methane concentrations in the porewater, $10 \mathrm{ml}$ sediment samples were taken with a cut-off syringe and injected into a vial containing $10 \mathrm{ml}$ $1 \mathrm{~N} \mathrm{NaOH}$, which was quickly closed with a rubber stopper and shaken intensely. After equilibration methane was measured in the headspace with a gaschromatograph (Packard, Model 438A) equipped with a flame ionization detector. Methane contents per sediment volume were corrected for water content to yield porewater concentrations.

Oxygen concentrations in the overlying water column were determined by the Winkler titration method in water samples taken by the rosette sampler or by water samplers attached to the VESP system.

Bacterial activities. $\mathrm{CO}_{2}$ fixation rates in the bacterial communities in the sediments were determined with the ${ }^{14} \mathrm{C}$-technique. Cut-off syringes $(5 \mathrm{ml})$ were pushed vertically into the sediment ( 2 parallels) to give subcores at 0 to 5,5 to 10,10 to 15 and 15 to $20 \mathrm{~cm}$ sediment depth. In parallel injections, $3 \times 9 \mu$ of a $\mathrm{H}^{14} \mathrm{CO}_{3}^{-}$solution (specific activity: $55 \mathrm{mCi} \mathrm{mmol}^{-1}$, $4 \mu \mathrm{Ci}$ per $100 \mu \mathrm{l}$ ) were injected to ensure a homogeneous distribution of the tracer in the subcore. Controls, with autoclaved sediment of the same horizons, were also injected. The samples were incubated for $24 \mathrm{~h}$ in darkness, at in situ temperature and atmospheric pressure. The reaction was stopped by transferring $1 \mathrm{~cm}$ sections of the subcores into centrifuge tubes filled with $5 \mathrm{ml} 0.3 \mathrm{~N}$ hydrochloric acid. After shaking, tubes were left open for 15 min to remove unconsumed tracer and then centrifuged. The supernatant was discarded and the procedure repeated with fresh $0.3 \mathrm{~N}$ hydrochloric acid. Finally the sediment pellet was dried for $48 \mathrm{~h}$ at $60^{\circ} \mathrm{C}$. To analyze the amount of ${ }^{14} \mathrm{C}$-tracer incorporated into cells, the pellet was homogenized, weighed, mixed with cellulose and burned in a sample oxidizer (Packard, Model 307). ${ }^{14} \mathrm{CO}_{2}$ released during the oxidation was absorbed by Carbosorb, and the radioactivity was determined in a liquid scintillation counter.

Dissimilatory sulfate reduction rates (SRR) were determined by incubating duplicate subcores with $37 \mathrm{kBq}$ of vertically injected ${ }^{35} \mathrm{~S}$-sulfate (carrier-free, Nen Life Science Products, Belgium) per cubic centimeter sediment. Three injections, in a triangular arrangement, were made into each subcore using a micromanipulator and a Hamilton syringe providing good horizontal and uniform vertical distribution of the tracer. After incubation for $6 \mathrm{~h}$ at in situ temperature $\left(5^{\circ} \mathrm{C}\right)$ in the dark, the sediment segments were removed to centrifugation tubes containing $20 \%$ zinc acetate $(\mathrm{w} / \mathrm{v})$. The total reduced inorganic sulfur formed was distilled following the 1-step acidic and chromium reduction procedure of Fossing \& Jørgensen (1989). Radioactivity of trapped hydrogen sulfide was measured in a liquid scintillation counter (Packard, 1900 CA Tricarb) and corrections for quenching were made. Sulfate reduction rates were then calculated according to Jørgensen (1978).

\section{RESULTS}

\section{Sea floor observations with the photo-TV sled}

Several photo-TV traverses at the upper and lower slope of the investigation area west of Karachi (close to Stns 257, 302, 304, 309) were run during the 'SO-130' cruise. Since this area belongs to the easternmost part of the Makran active margin with the subductionaccretionary wedge complex, we observed abundant signs of recent tectonic activity (cracks, faults) and large-scale dewatering and degassing of the organicrich and water-saturated sediments of the anoxic zone. 
'Pockmarks', gas expulsion structures, cold seeps, 'mud mounds', as well as the associated precipitates of whitish or blackish material (hardgrounds, see Von Rad et al. 1996), were observed.

Bacterial mats at the sediment surface were observed in the inner range of the OMZ, in water depths between 350 and $850 \mathrm{~m}$. No homogeneous large-scale mats were found, but small white to yellow patches of not more than $1 \mathrm{~m}$ in diameter, usually showing diffuse edges, were seen (Fig. 2A). In some cases mats had developed around small fissures in the sediment occurring at fault-controlled, slope-parallel steps on steep escarpments (Fig. 2B). In other cases, the bacterial mats had concentric structures and round or oval shapes with clear boundaries (Fig. 2C). These were similar to seeps described by Von Rad et al. (1996).
A few white spots also appeared to have developed around decaying drift-wood or other large pieces of organic material. In 2 cases (Stns 232 and 304) it was possible to obtain a sediment core from the margin of a white spot as described above, but we did not obtain sediment cores with an intact bacterial mat as seen with the TV sled (OFOS).

\section{Composition and morphology of the Thioploca/Beggiatoa community}

The sediment surface outside the visible white spots also showed components of bacterial mats but in much lower quantities. On the surface, small tufts of free filaments of variable diameter were discovered, which
Fig. 2. Bacterial mats in the Makran shelf region, shown by in situ photos taken by the photo-TV sled (OFOS). (A) White bacterial mat with diffuse outline and black, sulfidic spots, $650 \mathrm{~m}$ water depth (B) elongate bacterial mat, concentrated along a fault-controlled, slope-parallel step on a steep escarpment, $500 \mathrm{~m}$ water depth; (C) whitish mat with yellowish central part and distinct, oval-shaped outline, $850 \mathrm{~m}$ water depth. Scale: approximately $1 \mathrm{~m}$ between upper and lower margins of photos
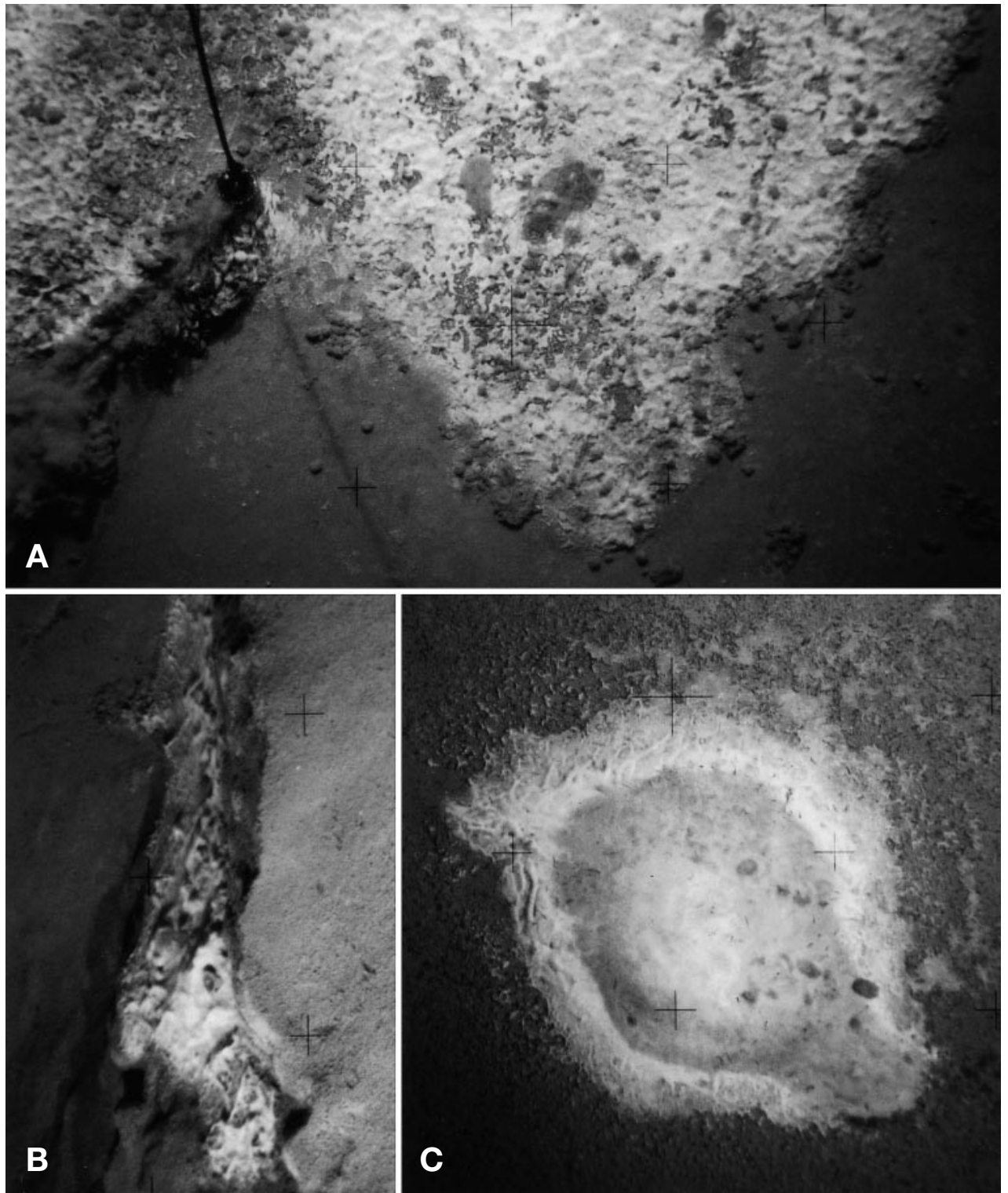
were barely visible with the naked eye, and sheathed Thioploca filaments were found under the sediment surface. Additionally, the surface was covered with a network of foraminiferan reticulopodia and single, free filaments of the Beggiatoa type that were only visible under the microscope.

As Thioploca and Beggiatoa filaments cannot be distinguished morphologically except by the presence or absence of a sheath, and as Thioploca filaments are able to move outside their sheath, it is not possible to discriminate reliably between these 2 genera by microscopic methods. Therefore, in the following we will use the term Thioploca for sheathed filaments. Filaments outside of sheaths will be referred to as 'free filaments'. Other sulfur-oxidizing filamentous bacteria like the rosette-forming Thiothrix were not found in the samples.

Thioploca filaments were composed of rectangular cells, giving the filaments a cylindrical, weakly segmented or non-segmented outer appearance. The diameter of filaments ranged from 3 to $75 \mu \mathrm{m}$, and the relation between length and width of the single cells changed from cylindric (diameter $\simeq$ length) in thinner filaments (Fig. 3G) to disc-like in thicker filaments (Fig. 3E). Tapering ends of filaments, often mentioned as an additional though not constant characteristic of Thioploca, were found in sheathed filaments, as well as in free ones (Fig. 3I), but more frequently the filament ends were rounded (Fig. 3F). By light microscopy many refractile intracellular sulfur granules were observed (Fig. 3F), which are indicative of sulfur-oxidizing activity. TEM photomicrographs of thin sections showed the presence of large central vacuoles in the cells and the position of the sulfur granules in the peripheral cytoplasmic part (Fig. 3J).

Thioploca filaments were combined to bundles of up to 20, but normally less than 10 filaments, and surrounded by a common sheath. The diameter of the sheaths varied between 50 and $400 \mu \mathrm{m}$, and the length was up to $20 \mathrm{~mm}$. In most cases these sheaths were only slightly transparent and encrusted with sediment particles (Fig. 3C, H). Sometimes, however, sheaths were so thin, that they were scarcely visible by light microscopy (Fig. 3G). Frequently we observed that sheaths were formed around 1 single filament (Fig. 3D). Thioploca sheaths were frequently split at 1 end in a root-like manner (Fig. 3A, B).

The morphology of free filaments was generally similar to the sheathed ones. Fig. 3I and Fig. 3K show typical examples of sulfur-containing filamentous bacteria at the sediment surface. Some of these aggregates were associated with Thioploca sheaths, others were adhering to detritus particles. In addition to filaments containing sulfur inclusions several types of thin filaments, including coiled ones (Fig. 3L), were present, which did not show refractile sulfur globules.

Both sheath-forming and free filaments were characterized by a great variation in diameter within the individual sample, and even within a single sheath. Fig. 4 shows the distribution of different filament diameters of free and sheathed filaments at 6 sites in the investigated area. Quite obviously the diameters followed distinct size classes: sheaths with very thin filaments (3 or $4 \mu \mathrm{m}$ diameter) were only found at the seep Stns 232, 302 and 304; those with medium-size filaments (8 to $24 \mu \mathrm{m}$ ), at all stations except Stns 302 and 309 ; and sheaths with filaments of larger diameters (30 to $52 \mu \mathrm{m}$ ) occurred at all stations and were most frequent at Stns 257, 302 and 309. Very large filaments (55 to $75 \mu \mathrm{m}$ ) were found in sheaths at Stns 223, 232, 257 and 302. Free filaments frequently had diameters that were different from those of the sheathed ones found at the same station (Fig. 4).

\section{Abundance, biovolume and depth distribution of Thioploca}

A detailed analysis of the number and distribution of Thioploca in 2 sediment cores was made at Stn 309, which was close to a seep site and without visible bacterial mat at the sediment surface. The number and depth distribution of Thioploca threads (including living

Fig. 3. Morphological features of filamentous bacteria in bacterial mats. (A) Complete Thioploca sheath of 18.5 mm length and $140 \mu \mathrm{m}$ diameter, showing 7 protruding filaments and split-up opposite end, scale bar = $1 \mathrm{~mm}$; (B) detail of split-up end of a Thioploca sheath, scale bar $=0.2 \mathrm{~mm}$; (C) end of Thioploca sheath with filaments of different diameter (8 to $18 \mu \mathrm{m})$ protruding, scale bar $=20 \mu \mathrm{m}$; (D) sheath built around a single Thioploca filament, scale bar $=20 \mu \mathrm{m}$; (E, F) Thioploca filaments of different diameters, outside of sheath, scale bar $=20 \mu \mathrm{m}$; (G) bundle of Thioploca filaments (40 and $10 \mu \mathrm{m}$ diameter) within unvisible, nonencrusted sheath, scale bar $=100 \mu m_{i}(\mathrm{H})$ encrusted Thioploca sheath with 3 protruding filaments, scale bar $=100 \mu \mathrm{m} ;(\mathrm{I})$ free Thioploca and/or Beggiatoa filaments associated with detritus on the sediment surface; note tapering ends of 2 filaments, scale bar $=100 \mu m_{i}(\mathrm{~J})$ ultrathin section through a Thioploca filament, partly through the large central vacuole (v) and partly through the peripheral cytoplasm showing vesicles with varying electron-dense material, probably sulfur storage globules (s), and other filamentous bacteria (f) of small diameter, scale bar $=1 \mu \mathrm{m}$; (K) large filamentous bacteria (50 to $55 \mu \mathrm{m}$ diameter) at the sediment surface, scale bar $=100 \mu m_{i}(L)$ coiled filamentous bacterium frequently associated with detritus particles, scale bar $=5 \mu$ m. A, B, G, H, I, K: light microscopy, dark-field; E, F: light microscopy, phase contrast; C, D, L: scanning electron micrographs; J: transmission electron micrograph 

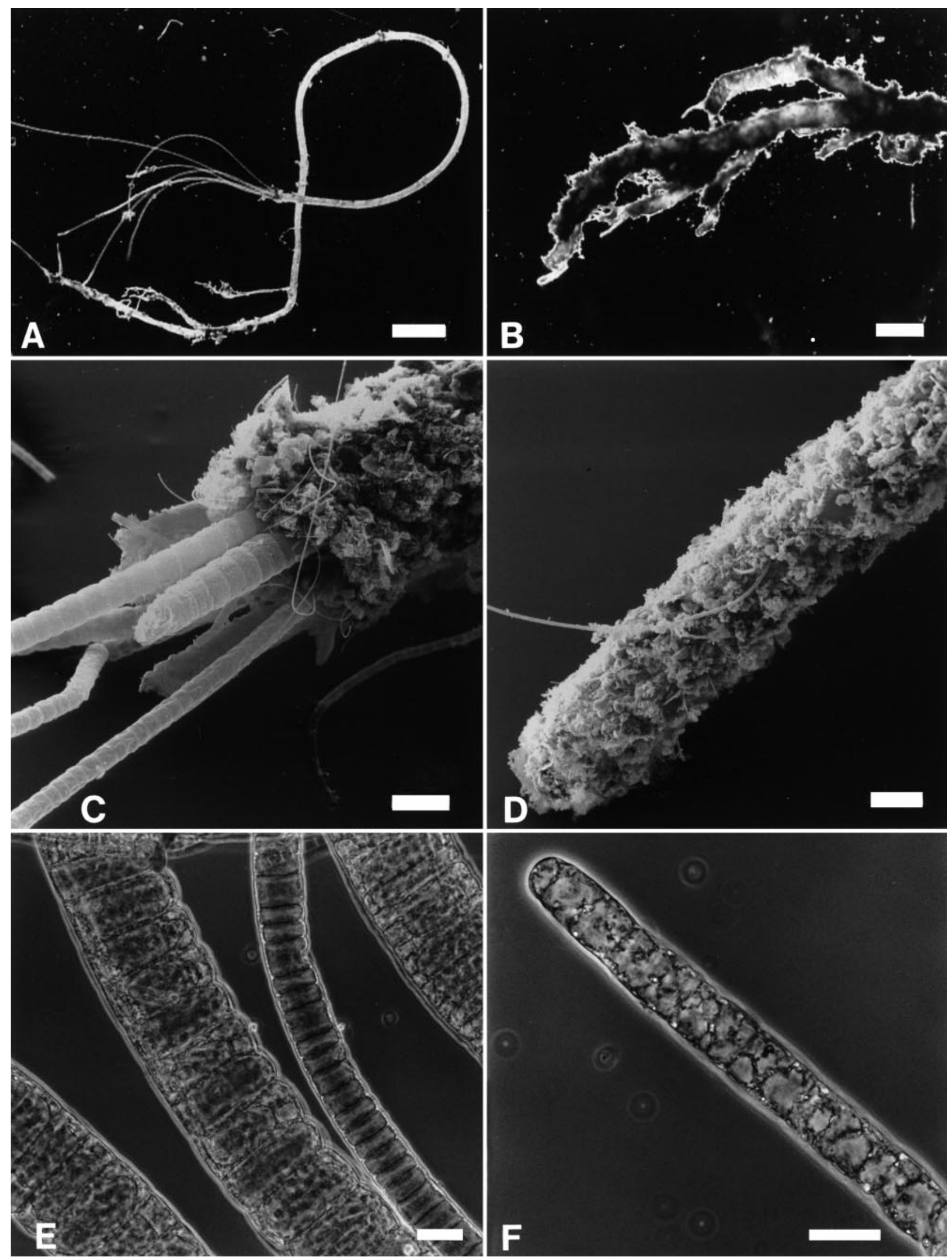


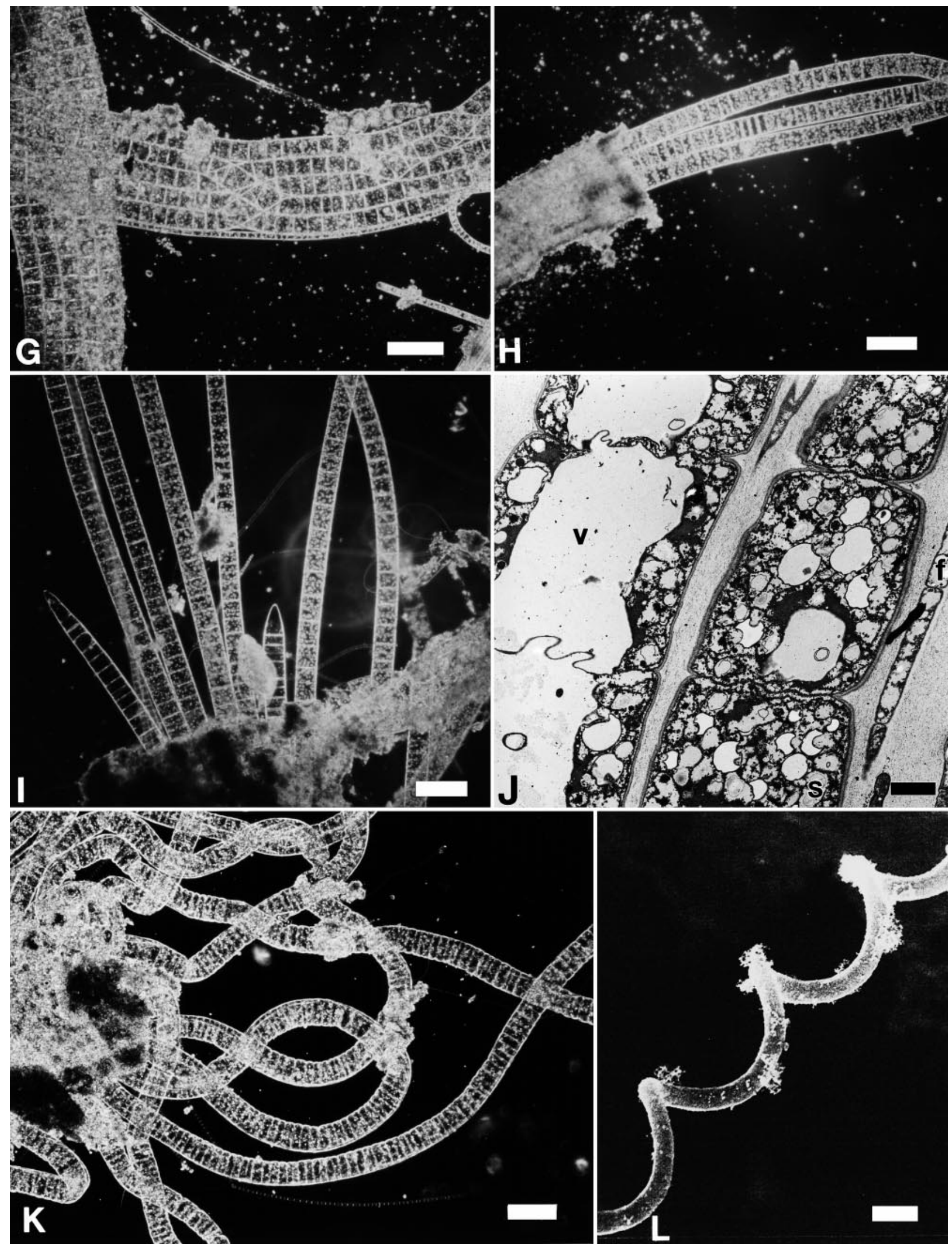

Fig. 3 (continued) 

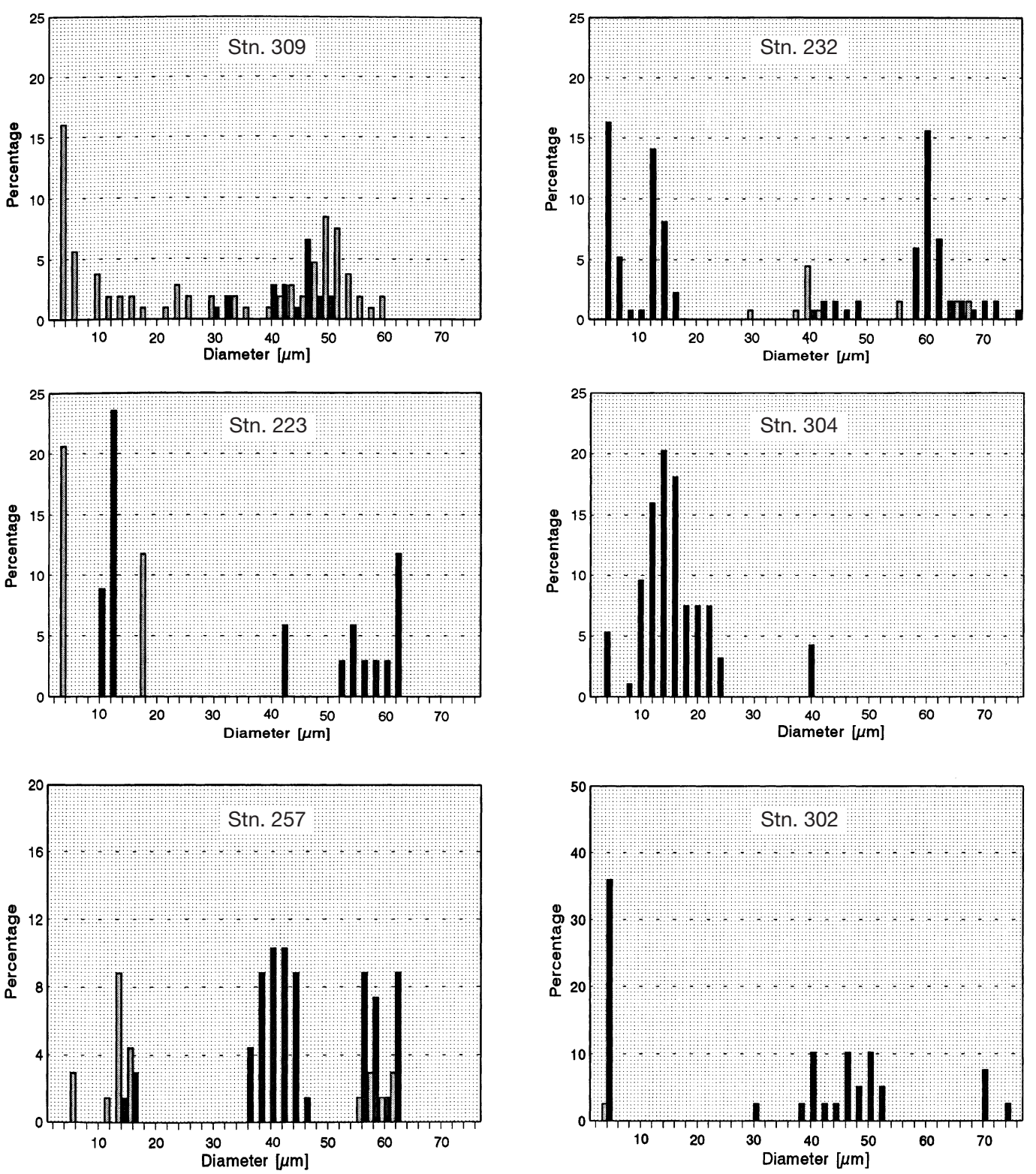

Fig. 4. Thioploca. Size distribution of filaments at 3 seep sites (Stns 232, 302, 304) and 3 near-seep sites (Stns 223, 257, 309) in the investigation area. Black columns indicate filaments within sheaths, grey columns filaments outside of sheaths, as percentage of total filaments at that station

and dead filaments) are shown in Fig. 5A. The highest density with roughly constant numbers was found between 1 and $9 \mathrm{~cm}$ sediment depth and sharply decreased below that. We counted a total of 102 to 169 sheaths below an area of $1 \mathrm{~cm}^{2}$. Due to frequent encrustations of the sheaths, it was normally not possible to differentiate between living and dead individuals. However, in some cases sheaths containing living filaments were detected down to $13 \mathrm{~cm}$ depth. In order to account for the different length of the sheaths, in Fig. 5B the length of all individuals was added up for each sediment horizon. This diagram shows more clearly that the highest biomass is between 1 and $3 \mathrm{~cm}$ sediment depth, declining gradually towards deeper horizons. A rough estimation of the total biovolume surrounded by the Thioploca sheaths in the upper $15 \mathrm{~cm}$ of sediment was obtained by a calculation considering additionally the mean diameter of the sheaths $(149.6 \mu \mathrm{m})$ and the above given number of bundles per area, resulting in a value of $155 \pm 38 \mathrm{~cm}^{3} \mathrm{~m}^{-2}$.

The sediment Stn 223 contained fewer Thioploca in comparison to Stn 309, and the depth distribution was somewhat shifted towards deeper sediment horizons between 2 and $12 \mathrm{~cm}$ depth. 


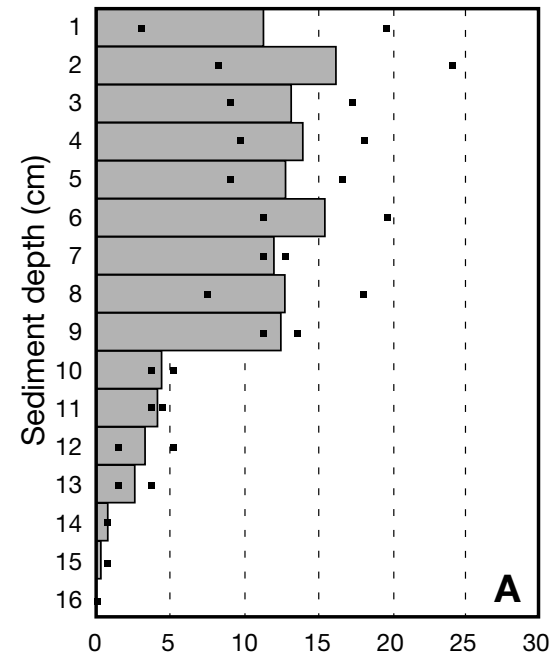

Number of Thioploca sheaths per $\mathrm{cm}^{3}$

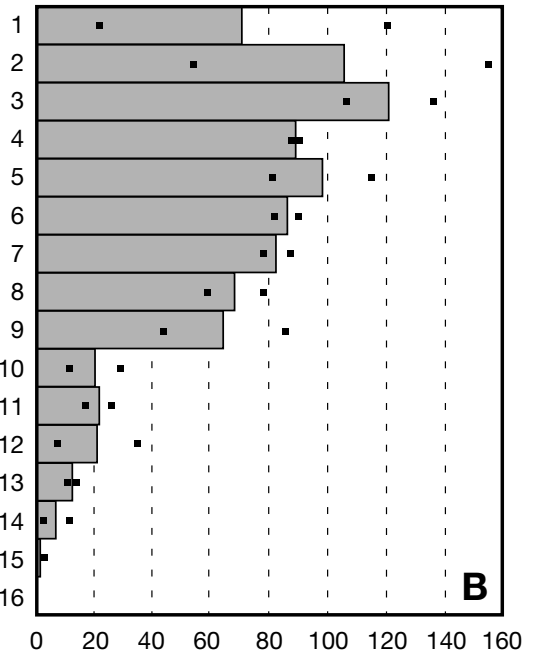

Total length $(\mathrm{mm})$ of sheaths per $\mathrm{cm}^{3}$

Fig. 5. Thioploca. Depth distribution of sheaths in the sediment of Stn 309 (A) Number of sheaths (with or without filaments); (B) numbers of sheaths multiplied by mean length in each horizon (= total length). Data are mean values of 2 parallel cores ( $\bullet$ : individual values)

Filament numbers of Thioploca in a sediment sample taken with a TV-controlled corer at the margin of a seep (Stns 232 and 304) were similar to those at Stn 309 , but in contrast to that site maximum Thioploca abundances were in the top layers between 0 and $5 \mathrm{~cm}$ and no sheaths were found below 8 to $10 \mathrm{~cm}$ depth.

\section{Geochemical data of the sediment}

The sediments in the investigated area that contained populations of Thioploca were situated in the inner part of the $\mathrm{OMZ}$, where oxygen concentrations of 0.3 to $0.6 \mathrm{mg} \mathrm{l}^{-1}$ were determined in the overlying water.

The surface sediment layer at Stn 309 consisted of a top layer (3 to $4 \mathrm{~cm}$ ) of light brown, fluffy depositions, followed by a stratified zone of silty grey and black layers until $10 \mathrm{~cm}$ depth, and by uniform dark-grey, more solid material below. The water content decreased from $73 \%$ at the surface to $59 \%$ at $20 \mathrm{~cm}$ depth (Fig. 6J). High proportions of organic matter (13.3 to $14.6 \%$ of dry weight) were determined throughout the top $20 \mathrm{~cm}$ (Fig. 6J). Nitrate concentrations varied between 0 and $14 \mu \mathrm{M}$, with distinct minima between 10 and $12 \mathrm{~cm}$ and between 16 and $18 \mathrm{~cm}$ (Fig. 6G). Methane concentrations were at background level, ranging from 4.1 to $7.9 \mu \mathrm{M}$ (Fig. 6H), and sulfide concentrations (Fig. 6E) were below the detection limit $(<0.2 \mu \mathrm{M})$. This indicates that the sample was not directly from a seep site. Sulfate concentrations decreased from $35 \mathrm{mM}$ at the surface to $22 \mathrm{mM}$ at $20 \mathrm{~cm}$ depth (Fig. 6B). The highest sulfate-reducing activity (193 nmol $\mathrm{cm}^{-3} \mathrm{~d}^{-1}$ ) was detected within the first centimeter below the sediment surface, and considerable activity also occurred below that, with smaller maxima at 5 to 6 and 10 to $11 \mathrm{~cm}$ depth (Fig. 6D). Area-integrated rates for the top $20 \mathrm{~cm}$ of sediment were $10.1 \mathrm{mmol} \mathrm{SO}_{4}{ }^{2-} \mathrm{m}^{-2} \mathrm{~d}^{-1}$. In the depth range between 5 and $20 \mathrm{~cm}$, we detected high concentrations of elemental sulfur with maximum values of $8 \mu \mathrm{mol} \mathrm{cm} \mathrm{cm}^{-3}$ between 8 and $10 \mathrm{~cm}$ and 3 to $4 \mu \mathrm{mol} \mathrm{cm} \mathrm{cm}^{-3}$ below that (Fig. 6F). The redox potential decreased from $450 \mathrm{mV}$ at the sediment surface down to values between 240 and $270 \mathrm{mV}$ below $6 \mathrm{~cm}$ depth (Fig. 6A). The drop of redox potential within the top $6 \mathrm{~cm}$ coincided with an increase of $\mathrm{pH}$ from 7.4 at the surface to 7.8 at $6 \mathrm{~cm}$ depth (Fig. $6 \mathrm{C}$ ); this was also the range characterized by a sharp gradient of $\mathrm{CO}_{2}$ fixation rates (Fig. 6I) from $6.3 \mathrm{nmol} \mathrm{CO}_{2} \mathrm{~cm}^{-3} \mathrm{~d}^{-1}$ at the surface to $1.1 \mathrm{nmol} \mathrm{CO}_{2} \mathrm{~cm}^{-3} \mathrm{~d}^{-1}$ at 4 to $5 \mathrm{~cm}$ depth.

The second site, Stn 223 (in the western part of the investigated area), was also situated within a seep field, but not within or at the margin of a seep. The sediment at this site differed in several aspects from that of Stn 309. The top $2 \mathrm{~cm}$ was characterized by a sharp gradient of nitrate, decreasing to $<4 \mu \mathrm{M}$ below that depth (Fig. 7G), and by higher $\mathrm{CO}_{2}$ fixation rates than at Stn 309 (Fig. 7I). A sulfate reduction maximum at the surface was lacking at this site (Fig. 7F), and rates

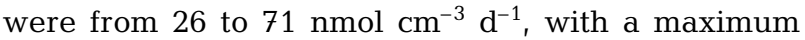
of $90 \mathrm{nmol} \mathrm{cm} \mathrm{cm}^{-3} \mathrm{~d}^{-1}$ in $14 \mathrm{~cm}$ depth. A black layer between 2 and $4 \mathrm{~cm}$ depth had high concentrations

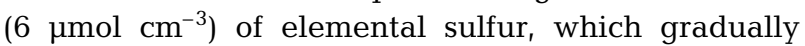
levelled off downcore (Fig. 7F). Soluble sulfide was not detectable within the top $15 \mathrm{~cm}$. Below $15 \mathrm{~cm}$ depth the redox potential markedly decreased to values below $0 \mathrm{mV}$ (Fig. 7A), coinciding with an increase of sulfide concentrations up to $19 \mu \mathrm{M}$ (Fig. 7E), higher methane concentrations (Fig. 7H), a shift of $\mathrm{pH}$ from 8.1 to 7.9 (Fig. $7 \mathrm{C}$ ), and a shift from soft to more solid sediment with lower water content (Fig. 7J).

The sediments from the margin of seep sites, Stn 232 and 304 , were characterized by a very soft, lightyellow, fluffy layer in the top $2 \mathrm{~cm}$, underlain by a narrow (about $3 \mathrm{~mm}$ ) layer of whitish material and by dark-grey/black layers. Below $15 \mathrm{~cm}$ the sediment became more solid and the color turned into uniform 

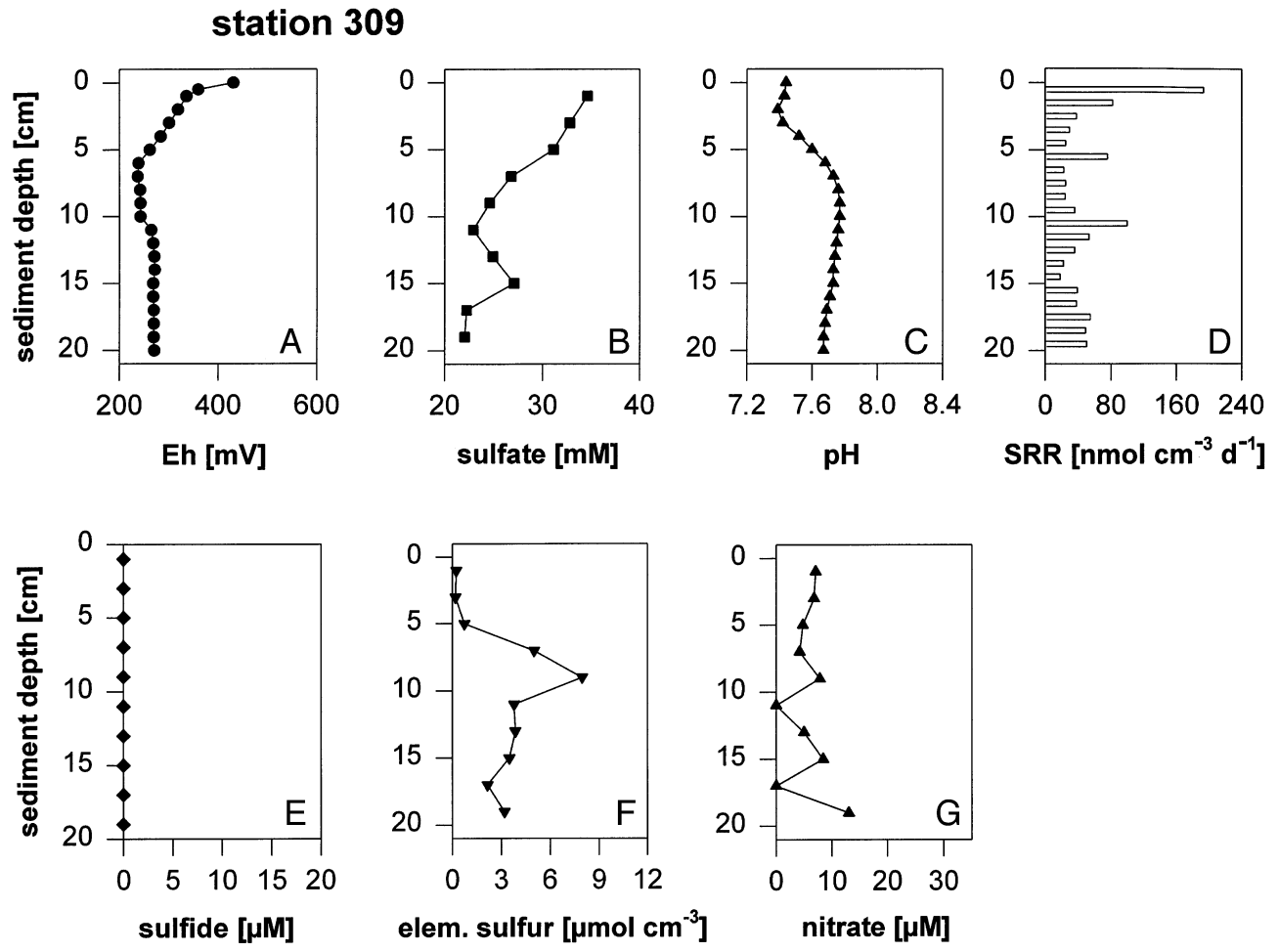

Fig. 6. Geochemical data and microbial activities in the sediment of $\mathrm{Stn}$ 309: (A) redox potential (Eh), (B) sulfate, (C) $\mathrm{pH}_{\text {, }}$ (d) sulfate reduction rate (SRR), (E) sulfide, (F) elemental sulfur, $(\mathrm{G})$ nitrate, (H) methane, (I) $\mathrm{CO}_{2}$ fixation rate, $(\mathrm{J})$ water content and organic matter (loss on ignition)
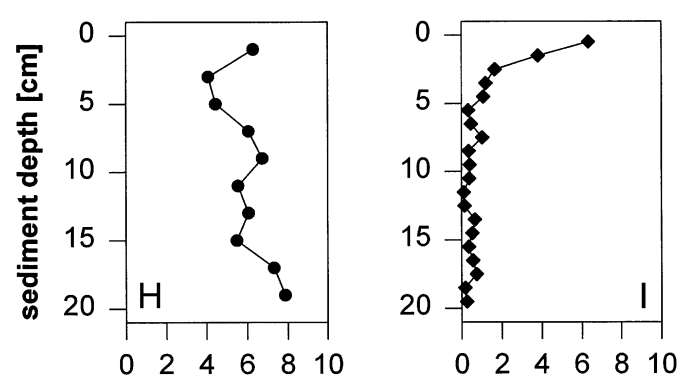

loss on ignition $[\% \mathrm{dw}]$

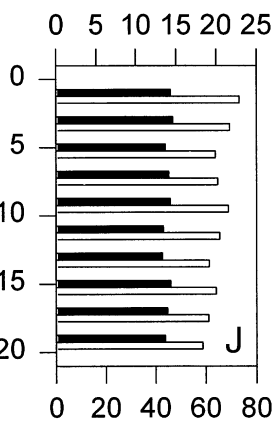

dark olive-green. Geochemically the sediment at Stn 232 showed a clear zonation: (1) an upper zone (5 to $6 \mathrm{~cm}$ ) characterized by positive redox potentials of $>360 \mathrm{mV}$ (Fig. 8A), high sulfate concentrations (34 to $35 \mathrm{mM}$, Fig. 8B), nitrate concentrations of $>5 \mu \mathrm{M}$ (Fig. 8E), and lacking soluble sulfide (Fig. 8C); (2) an intermediate layer between 6 and $11 \mathrm{~cm}$ sediment depth with steep gradients, especially in redox potential; and (3) a sulfide-rich layer below which redox potentials were around $0 \mathrm{mV}$ and nitrate was not present. Elemental sulfur accumulated in 2 horizons, one at $4 \mathrm{~cm}$ depth, which is within the layer of high sulfate consumption, and another at $7 \mathrm{~cm}$ depth, within the main redox shift. The sediment at Stn 304 was characterized by steeper gradients of all parameters than those at Stn 232. The redox potential dropped from +180 to $-170 \mathrm{mV}$ between 10 and $14 \mathrm{~cm}$ depth, and sol- uble sulfide concentrations increased up to $1.2 \mathrm{mM}$ within the same depth range (Fig. 9A,C). Sulfate concentrations decreased from seawater concentrations at the surface to $14 \mathrm{mM}$ at $17 \mathrm{~cm}$ depth, indicating high sulfate reduction activity (Fig. 9B). Very high concentrations of elemental sulfur (about $10 \mu \mathrm{mol} \mathrm{cm}{ }^{-3}$, Fig. 9D) were present in a layer above the sulfide peak, within the zone of the steep redox gradient. Nitrate was available within the sediment in a concentration range of 2 to $5 \mu \mathrm{M}$, declining from $32 \mu \mathrm{M}$ in the supernatant water within the top $1 \mathrm{~cm}$ of sediment (Fig. 9E).

\section{DISCUSSION}

The occurrence of Thioploca communities in the northeastern Arabian Sea further extends the range of 

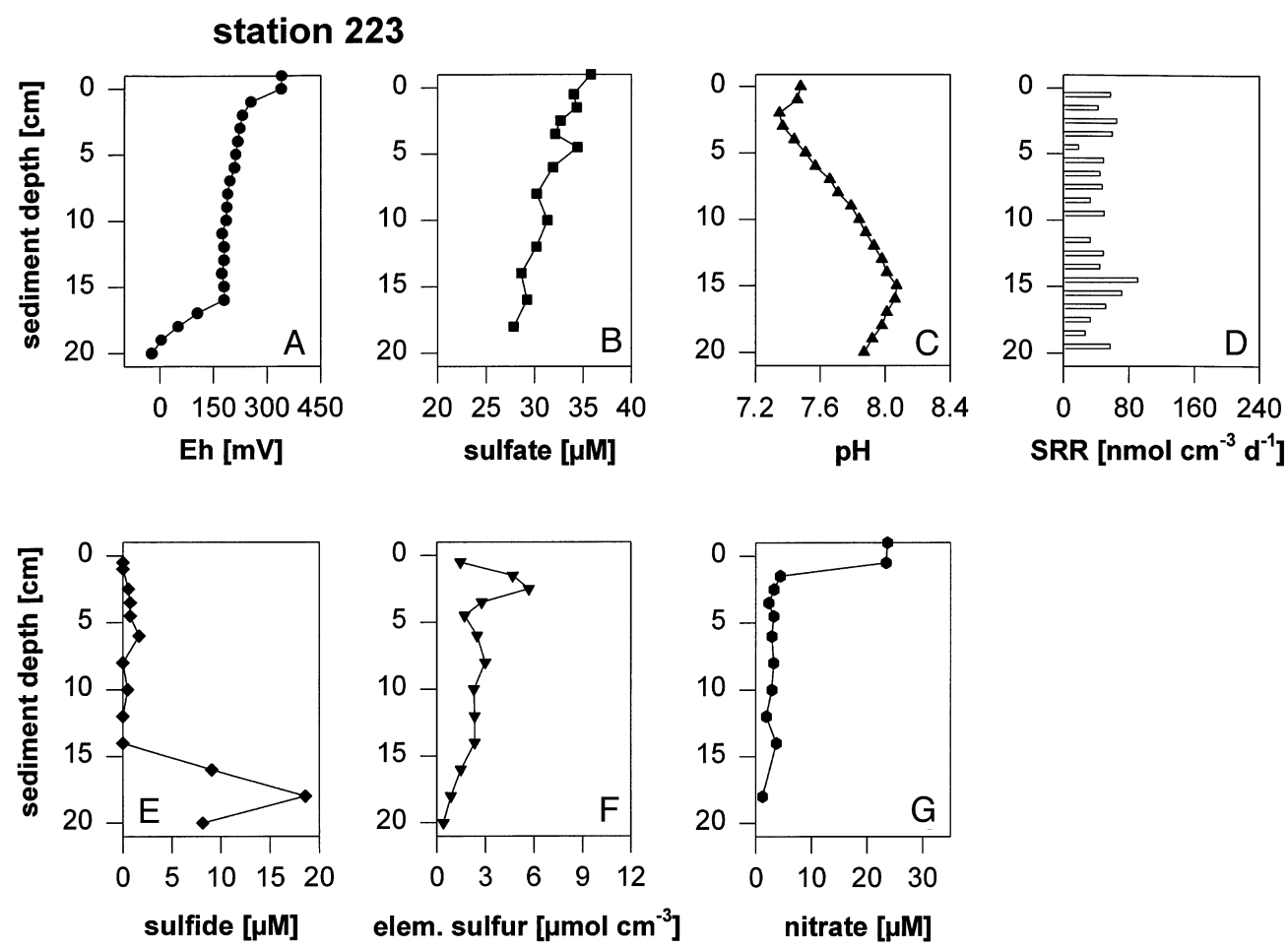

elem. sulfur $\left[\mu \mathrm{mol} \mathrm{cm} \mathrm{cm}^{-3}\right]$

\section{loss on ignition $[\% \mathrm{dw}]$}

$0 \quad 510152025$
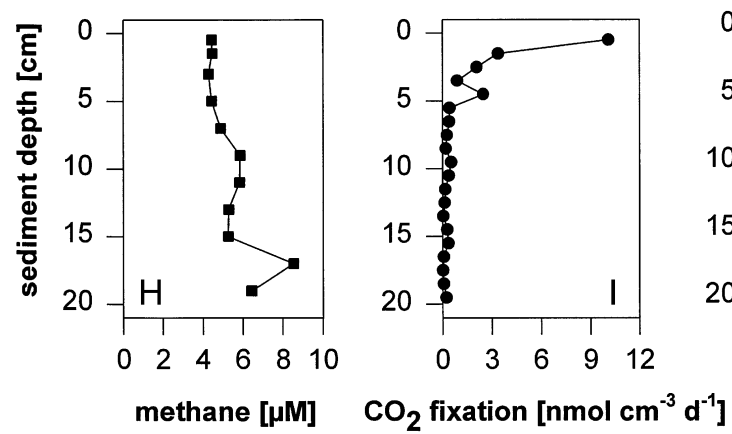

Fig. 7. Geochemical data and microbial activities in the sediment of Stn 223: (A) redox potential (Eh), (B) sulfate, (C) $\mathrm{pH}$, (D) sulfate reduction rate (SRR), (E) sulfide, (F) elemental sulfur, (G) nitrate, $(\mathrm{H})$ methane, (I) $\mathrm{CO}_{2}$ fixation rate, $(\mathrm{J})$ water content and organic matter (loss on ignition) habitats known for these extraordinary bacteria. It confirms the view that these bacteria can be expected in marine sediments from the upper continental slope, overlain by a water column with high productivity in the euphotic layers and permanent oxygen-minimum conditions above the sediment. As at the well-known Thioploca site off the Chilean coast (Ferdelman et al. 1997), the surface sediment horizons harboring Thioploca are characterized by considerable sulfate reduction rates but generally very low concentrations of soluble sulfide. An interesting observation in the Arabian Sea habitat is the occurrence of Thioploca close to cold seep sites, where these organisms were found in the top 8 to $10 \mathrm{~cm}$ of sediment under low-sulfide conditions, though high sulfide concentrations were measured in deeper layers. Thioploca communities at seep sites were reported only from a few localities, for example at a cool, diffuse, hydrothermal vent field near the island of Milos, Greece (Dando \& Hooper 1996), or in cold seeps of the Monterey Canyon (Buck \& Barry 1997).

The Thioploca community described in this study appears to be similar to the one reported from the continental slope off Oman (Levin et al. 1997), though it is morphologically more diverse. The organisms from Oman correspond to the medium size class of the Makran specimens (30 to $40 \mu \mathrm{m}$ diameter, 2 to 10 filaments per sheath, length of sheath 6 to $20 \mathrm{~mm}$, outer diameter of sheath up to $200 \mu \mathrm{m})$. The number of Thioploca bundles found off Oman (minimum estimation by sieving through $300 \mu \mathrm{m}$ screen: $22117 \pm 9397 \mathrm{~m}^{-2}$ ) is far lower than in this investigation $(1.02$ to $1.69 \times$ $10^{6} \mathrm{~m}^{-2}$ at Stn 309 ), which may in part be the result of differences in the counting procedure. Another common feature is the similar depth distribution within the 

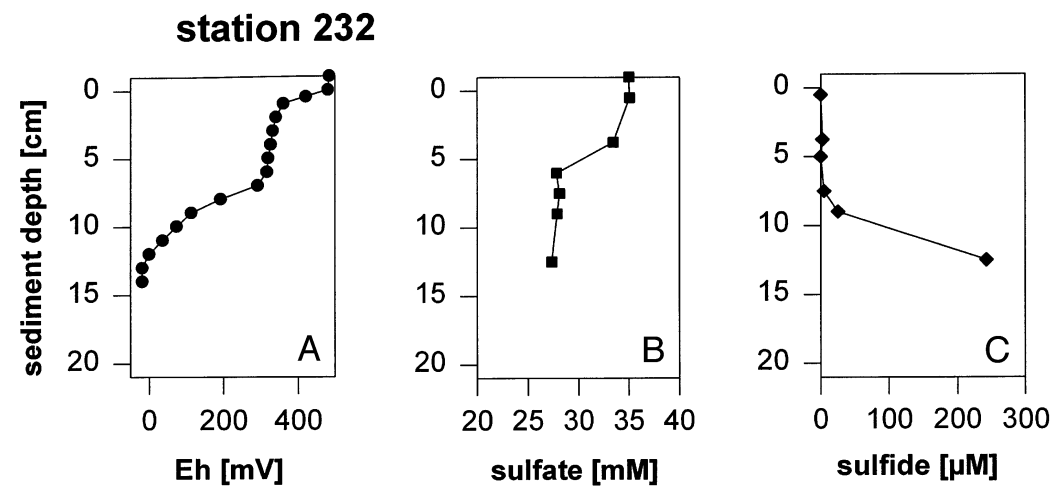

to the situation off the Chilean coast, where the highest Thioploca biomass was found in the first centimeter below the sediment surface (Schulz et al. 1996).

The biovolume estimations for the Chilean Thioploca community (up to $800 \mathrm{~g}$ wet weight $\mathrm{m}^{-2}$, Schulz et al. 1996) were determined by weighing sheaths with filaments, while the data in this study $\left(155 \pm 38 \mathrm{~cm}^{3} \mathrm{~m}^{-2}\right)$ refer to biovolume (sheaths including filaments). This relation, though not directly comparable, shows that in the Makran community Thioploca has a lower biomass than off Chile. However, it has to be taken into account that the biomass of such bacterial mats is to a high degree subject to seasonal variations (Fossing et al. 1995). It is influenced by sinking phytoplankton blooms and the resulting variations in oxygen and nitrate concentrations. The sampling of the Makran sedisediments $(73 \%$ of all individuals present from 0 to $20 \mathrm{~cm}$ were found below $5 \mathrm{~cm}$ in the Oman sediments, 44 to $62 \%$ in Makran sediments at Stn 309). The occurrence near the surface in the sediments from the margin of Makran seep sites (Stns 232 and 304) compares

- Geochem data of the sediment of (C) sulfide, (D) elemental sulfur, (E) nitrate ments was in April, before the main period of primary production during the summer monsoon. Therefore, it can be assumed that the situation found in April represents a state of comparably weak development of the bacterial mats, if compared to the time of maximum productivity in August/September, where layers of olive-green, fluffy material were observed on the top of box cores during a previous expedition. A comparable seasonality for bacterial activity was also observed in the deep Arabian Sea by Boetius et al. (2000). Furthermore, one must consider that the Thioploca biomass in this study was estimated only for sediment cores without white bacterial mats, and that samples from within the mats possibly would show increased values.

Bacterial mats consisting of Thioploca are typically described as a white 'lawn', where filaments protrude a few centimeters into the overlying water (Jørgensen \& Gallardo 1999). Similar observations were never made in the Makran area, neither with the underwater video system in the natural habitat, nor in fresh sediment samples or cores that had been stored for some days in ambient seawater on board the ship. Actually, it could not be deter-
Fig. 9. Geochemical data of the sediment of Stn 304: (A) redox potential (Eh), (B) sulfate, (C) sulfide, (D) elemental sulfur, (E) nitrate 
mined whether the tufts with free filaments, which were frequently observed on the sediment surface or entangled with the network of foraminiferan rhizopodia, originated from Thioploca sheaths close below the surface or were free-living Beggiatoa.

According to Jørgensen \& Gallardo (1999) 4 different size classes of Thioploca can be distinguished in the marine environment, based on filament diameter: $T$. marina $(2.5$ to $5 \mu \mathrm{m}), T$. chileae (12 to $20 \mu \mathrm{m}), T$. araucae (30 to $43 \mu \mathrm{m})$ and an undescribed species (60 to $125 \mu \mathrm{m})$. Two of these, T. chileae and T. araucae, are validly described species and were phylogenetically characterized on the basis of their 16S rRNA sequence (Teske et al. 1995). Each of these size classes was detected in the sediments of the Makran shelf, constituting varying proportions of the total Thioploca community. However, the total number of investigated cores and filaments was too low to give quantitative data on the distribution of each size class or to allow a correlation with other parameters. While the 2 smaller size classes fit quite well into the diameter range given by Jørgensen \& Gallardo (1999), the diameters of the $T$. araucae group in the Makran area extend to $>50 \mu \mathrm{m}$ (instead of $43 \mu \mathrm{m}$ ). Furthermore, the high frequency of very large filaments with diameters between 55 and $75 \mu \mathrm{m}$ is remarkable, as this size is only occasionally observed off Chile (Schulz et al. 1996). Further differences between both Thioploca communities are the number of filaments per sheath, which may be up to 100 in Chile and $<20$ in Makran, and the dimensions of the sheaths, which can be 10 to $15 \mathrm{~cm}$ long with diameters of $1.5 \mathrm{~mm}$ in Chile (Fossing et al. 1995) and only $<2 \mathrm{~cm}$ long and $<0.4 \mathrm{~mm}$ thick in Makran. One reason for the smaller size and biomass of Thioploca in the Makran area might be the lower production of sulfide. A comparison of areal sulfate reduction rates (0 to $10 \mathrm{~cm}$ sediment depth) in the Makran area with those at the Chilean shelf (9.6 to $74.5 \mathrm{mmol} \mathrm{SO}_{4}{ }^{2-}$ reduced per square meter per day; Ferdelman et al. 1997) shows that rates were distinctly lower in the Makran sediments ( 5.5 to $5.8 \mathrm{mmol} \mathrm{m}^{-2} \mathrm{~d}^{-1}$ ).

Additionally, the smaller length of the Thioploca sheaths from Makran and their position in deeper sediment layers than in Chile must have consequences on the nutritional strategy of the filaments. For the Chilean Thioploca community it has been shown that sheaths form a network from the surface down to $5-10 \mathrm{~cm}$ depth, where the filaments easily glide up and down, transporting nitrate from the surface within their vacuoles down to sediment horizons with sulfide production (Fossing et al. 1995). A vertical movement to this extent is hardly imaginable for the filaments of the Makran area, because sheaths are significantly shorter, and the filaments would have to leave their sheaths completely and to move freely in the inter- stitial space. Free filaments, however, did not occur below $1 \mathrm{~cm}$ depth and were only observed near the sediment surface, where a clear distinction between Beggiatoa and Thioploca could not be made.

Assuming that Thioploca oxidizes sulfide by denitrification, which has been shown for natural samples from Chile (Otte et al. 1999), it has to be hypothesized that nitrate-containing sediment horizons are close to horizons with sulfate-reducing activity or that both substrates co-occur. Regarding the situation at Stn 309, it is obvious that zones with high sulfate reduction activity and sufficient nitrate contents alternate down to $20 \mathrm{~cm}$ sediment depth, and that there is no need for long migrations of more than 1 or $2 \mathrm{~cm}$ for the filaments. However, the distribution of low numbers of Thioploca at Stn 223 between 2 and $12 \mathrm{~cm}$ is difficult to explain, since these organisms lived within a zone of moderate sulfate reduction activity and very low nitrate concentrations (1 to $4 \mu \mathrm{M}$ ). Schulz et al. (1999) describing a large sulfur bacterium (Thiomargarita namibiensis) from the Namibian coast, propose the following life strategy for these non-motile bacteria, which live between 0 and $14 \mathrm{~cm}$ sediment depth and face the same problem as the small Thioploca species at the Makran shelf: oxidation of sulfide with nitrate though the 2 substrates do not coexist in sufficient amounts. By storage of elemental sulfur, as well as nitrate, such bacteria may endure long periods of substrate limitation and thrive again, if the loose sediment is resuspended or if the chemical situation in the overlying water column changes. Living cells of T. namibiensis were found in samples stored for $2 \mathrm{yr}$ without an addition of sulfide or nitrate (Schulz et al. 1999). In this context it is interesting that the Thioploca population of the Namibian shelf is much less dense than off the Chilean coast and that, due to high fluidity and instability of the sediments, this species is prevented from building vertical sheaths (Schulz et al. 1999).

The SRRs determined in the present study were

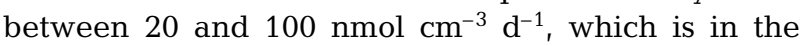
same range as rates measured in coastal sediments not impacted by upwelling or eutrophication (20 to $150 \mathrm{nmol} \mathrm{cm}{ }^{-3} \mathrm{~d}^{-1}$; Ferdelman et al. 1997). In spite of these considerable SRRs, sulfide concentrations were very low in the investigated sediments. On the other hand, high concentrations of elemental sulfur with maxima in a depth range inhabited by Thioploca were present above the layers containing measurable amounts of sulfide. Similar relations were demonstrated in other marine sediments (Thamdrup \& Canfield 1996, Podgorsek \& Imhoff 1999) and for OMZ sediments off the coast of Chile (Ferdelman et al. 1997). Two possible mechanisms might provide sufficient supply with reduced sulfur compounds for Thioploca: (1) utilization of colloidal elemental sulfur as 
an electron donator or (2) a close spatial coupling between sulfate-reducing and sulfide-oxidizing bacteria, as discussed by Jørgensen \& Gallardo (1999). These authors described thin filamentous bacteria, identified by oligonucleotide probes as Desulfonema sp., on the sheaths of Thioploca from Chile. Cells with identical morphology were not observed on Thioploca sheaths from the Makran area, but other morphological types of sulfate-reducing bacteria could replace Desulfonema in this region.

Low sulfide concentrations within a zone of high sulfate reduction activity can also be effected by iron scavenging the soluble sulfide produced. Ferdelman et al. (1997) reported that more than $50 \%$ of reduced sulfate in sediments off the Chilean coast accumulated in the pyrite pool. In some of the investigated Makran sediment layers (for example Stn 309, 5 to $15 \mathrm{~cm}$ depth) high SRRs are correlated with high amounts of acidvolatile and chromium-reducible sulfides (AVS/CRS, data not shown), which indicates that iron sulfides are precipitated there. Total iron contents in the top $10 \mathrm{~cm}$ sediment at Stn 309 were between 600 and $650 \mu \mathrm{mol}$ $\mathrm{g}^{-1}$ dry weight (data not shown).

If we assume that the Thioploca/Beggiatoa community is mainly responsible for the chemoautotrophic $\mathrm{CO}_{2}$ fixation activity, using nitrate as an electron acceptor for the oxidation of sulfide, then it could be expected that the depth distribution of these bacteria is reflected by the activity profile of $\mathrm{CO}_{2}$ fixation in the sediment. However, the maximum activity of this process at both investigated sites is within the top $2 \mathrm{~cm}$, decreasing rapidly towards depth, and thus does not match with the Thioploca distribution. It has to be considered that the applied method to measure $\mathrm{CO}_{2}$ fixation is not specific for the ribulose bisphosphate pathway, but may comprise also other pathways of $\mathrm{CO}_{2}$ fixation. Ferdelman et al. (1997), finding a very similar depth distribution of $\mathrm{CO}_{2}$ fixation in the sediments of the Chilean shelf, calculated that Thioploca is only responsible for 16 to $34 \%$ of the total sulfide removal in these sediments. They showed that only $6 \%$ of the fixed $\mathrm{CO}_{2}$ was associated with Thioploca and that high numbers of autotrophic acetogenic bacteria were abundant in the top $3 \mathrm{~cm}$ of sediment. $\mathrm{CO}_{2}$ fixed into cell material by these bacteria or excreted acetate incorporated by several other groups of bacteria might be responsible for part of the measured $\mathrm{CO}_{2}$ fixation maximum at the sediment surface. Additionally, other bacteria able to oxidize sulfide with nitrate, like Thiomicrospira denitrificans or Thiobacillus denitrificans, or bacteria using other substrates like elemental sulfur or ammonia could be involved in chemoautotrophic $\mathrm{CO}_{2}$ fixation.

Though the occurrence of Thioploca in the OMZ sediments off Makran is not as conspicuous as in other areas, where these organisms protrude above the sediment surface, it was shown in this study that Thioploca lives in fairly high numbers and biomass within the top $10 \mathrm{~cm}$ of these sediments, and that there is a high diversity within this genus, probably comprising at least 3 to 4 morphologically different species.

Acknowledgements. We are grateful for the professional support of Captain Papenhagen and his crew on board the RV 'Sonne'. Furthermore we thank Nikolaus von Mirbach for providing alkalinity data of the sediments. This study was supported by the Federal Ministry of Education, Research, and Technology, Bonn (Project No. 03G0130).

\section{LITERATURE CITED}

Boetius A, Ferdelman T, Lochte K (2000) Bacterial activity in sediments of the deep Arabian Sea in relation to vertical flux. In: Pfannkuche O, Lochte K (eds) The biogeochemistry of the deep Arabian Sea. Deep-Sea Res Part II: Topical Studies in Oceanography 47:2832-2875

Buck KR, Barry JP (1997) Monterey Bay cold seep infauna: quantitative comparison of bacterial mat meiofauna with non-seep control sites. In: Biscoito M, Cary C, Dixon D, Wilson C (eds) Proc 1st Int Symp Deep-Sea Hydrotherm Vent Biol, Vol 39, Station Biologique de Roscoff, Roscoff, p 333-335

Cline JD (1969) Spectrophotometric determination of hydrogen sulfide in natural waters. Limnol Oceanogr 14:454-458

Dando PR, Hooper LE (1996) Hydrothermal Thioploca-more unusual bacterial mats from Milos. BRIDGE Newslett 11: 45-47

Ferdelman TG, Lee C, Pantoja S, Harder J, Bebout BM, Fossing $H$ (1997) Sulfate reduction and methanogenesis in a Thioploca-dominated sediment off the coast of Chile. Geochim Cosmochim Acta 61:3065-3079

Fossing H, Jørgensen BB (1989) Measurement of bacterial sulfate reduction in sediments: evaluation of a single-step chromium reduction method. Biogeochemistry 8:205-222

Fossing H, Gallardo VA, Jørgensen BB, Hüttel M, Nielsen LP, Schulz H, Canfield DE, Forster S, Glud RN, Gundersen JK, Küver J, Ramsing NB, Teske A, Thamdrup B, Ulloa O (1995) Concentration and transport of nitrate by the matforming sulphur bacterium Thioploca. Nature 374:713-715

Gallardo VA (1977) Large benthic microbial communities in sulphide biota under Peru-Chile Subsurface Countercurrent. Nature 268:331-332

Gallardo VA, Klingelhoeffer E, Arntz W, Graco M (1998) First report of the bacterium Thioploca in the Benguela ecosystem off Namibia. J Mar Biol Assoc UK 78:1007-1010

Hagen KD, Nelson DC (1996) Organic carbon utilization by obligately and facultatively autotrophic Beggiatoa strains in homogeneous and gradient cultures. Appl Environ Microbiol 62:947-953

Jannasch HW, Nelson DC, Wirsen CO (1989) Massive natural occurrence of unusually large bacteria (Beggiatoa sp.) at a hydrothermal deep-sea vent site. Nature 342:834-836

Jørgensen BB (1978) A comparison of methods for the quantification of bacterial sulfate reduction in coastal marine sediments. I. Measurement with radiotracer techniques. Geomicrobiol J 1:29-47

Jørgensen BB, Gallardo VA (1999) Thioploca spp.: filamentous sulfur bacteria with nitrate vacuoles. FEMS Microbiol Ecol 28:301-313 
Levin L, Gage J, Lamont P, Cammidge L, Martin C, Patience A, Crooks J (1997) Infaunal community structure in a lowoxygen, organic rich habitat on the Oman continental slope, NW Arabian Sea. In: Hawkins LE, Hutchinson S (eds) The response of marine organisms to their environments. Proc 30th Mar Biol Symp, University of Southampton, Southampton, p 223-230

McHatton SC, Barry JP, Jannasch HW, Nelson DC (1996) High nitrate concentrations in vacuolate, autotrophic marine Beggiatoa spp. Appl Environ Microbiol 62:954-958

Otte S, Kuenen JG, Nielsen LP, Paerl HW, Zopfi J, Schulz HN, Teske A, Strotmann B, Gallardo VA, Jørgensen BB (1999) Nitrogen, carbon, and sulfur metabolism in natural Thioploca samples. Appl Environ Microbiol 65: 3148-3157

Podgorsek L, Imhoff JF (1999) Tetrathionate production by sulfur oxidizing bacteria and the role of tetrathionate in the sulfur cycle of Baltic Sea sediments. Aquat Microb Ecol 17:255-265

Schulz HN, Jørgensen BB, Fossing HA, Ramsing NB (1996) Community structure of filamentous, sheath-building sulfur bacteria, Thioploca spp., off the coast of Chile. Appl Environ Microbiol 62:1855-1862

Schulz HN, Brinkhoff T, Ferdelman TG, Hernández Mariné

Editorial responsibility: Gerhard Rheinheimer (Contributing Editor), Kiel, Germany
M, Teske A, Jørgensen BB (1999) Dense populations of a giant sulfur bacterium in Namibian shelf sediments. Science 284:493-495

Teske A, Ramsing NB, Küver J, Fossing H (1995) Phylogeny of Thioploca and related filamentous sulfide-oxidizing bacteria. Syst Appl Microbiol 18:517-526

Thamdrup B, Canfield DE (1996) Pathways of carbon oxidation in continental margin sediments off central Chile. Limnol Oceanogr 41:1629-1650

Von Rad U, Rösch H, Berner U, Geyh M, Marchig V, Schulz $H$ (1996) Authigenic carbonates derived from oxidized methane vented from the Makran accretionary prism off Pakistan. Mar Geol 136:55-77

Von Rad U, Berner U, Delisle G, Doose-Rolinski H, Fechner $\mathrm{N}$, Linke $\mathrm{P}$, Lückge A, Roeser HA, Schmaljohann R, Wiedicke $M$, the 'SONNE' 122/130 Scientific Parties (2000) Gas and fluid venting at the Makran Accretionary Wedge off Pakistan. GeoMar Lett 20:10-19

Von Stackelberg U (1972) Faciesverteilung in Sedimenten des indisch-pakistanischen Kontinentalrandes (Arabisches Meer). Meteor Forschungsergeb Reihe C 9:1-73

Wyrtki K (1973) Physical oceanography of the Indian Ocean. In: Zeitzschel B (ed) The biology of the Indian Ocean. Springer-Verlag, Berlin, p 18-36

Submitted: March 14, 2000; Accepted: June 27, 2000 Proofs received from author(s): January 30, 2001 